\title{
Evaluation of anti-phenolic glycolipid-I IgM and CD4/CD8 T cell subsets value as high risk determination indicator for individuals residing in a leprosy endemic area in Indonesia
}

\author{
Mochammad Hatta
}

\begin{abstract}
Abstrak
Penelitian ini menilai antibodi IgM terhadap Phenolic Glycolipid-I (PGL-I) M. leprae dan jumlah subset sel T(CD4 dan CD8) untuk menentukan derajat resiko menderita kusta di antara individu melalui survei penduduk di daerah endemik Kusta. Di antara 2349 dari 3074 penduduk yang diperiksa, angka seropositif pada penduduk tersebut secara umum dan kontak serumah sangat tinggi dan ditemukan secara berturut-turut sebesar 40,2\% dan 50,4\%. Angka rata-rata CD4 dan CD8 dari subset sel $T$ pada penduduk secara umum ditemukan berturut-turut sebesar $849 \pm 20$ dan $646 \pm 19$. Angka rata-rata CD4 dan CD8 dari subset sel T pada kontak serumah ditemukan berturut-turut sebesar $785 \pm 13$ dan $572 \pm 15$. Tidak ada perbedaan bermakna dalain jumlah subset sel T (CD4 dan CD8) antara penduduk secara umum dan kontak serumah. Pada penduduk secara umum, angka rata- rata CD4 dan CD8 pada individu dengan antibodi IgM terhadap PGL-I positif berbeda secara bermakna dibandingkan dengan pada individu dengan antibodi IgM terhadap PGL-I negatif. Pada penelitian ini antibodi IgM positif tidak selalu menggambarkan manifestasi klinis kusta, namun penemuan IgM positif disertai rendahnya jumlah CD4 dari subset sel T masih mungkin menunjang teori tentang resiko tinggi untuk menjadi kusta tipe lepromatosa.
\end{abstract}

\begin{abstract}
This study reports the evaluation of the presence of IgM antibody to Phenolic Glycolipid-I (PGL-I) of M. leprae and T cell subsets (CD4 and CD8) count to determine the high risk to contract leprosy among individuals through a total population survey in an area where leprosy is endemic, in Indonesia. Among the 2349 individuals of the total population of 3074 people, the seropositive rates in general inhabitants and household contacts were very high $(40.2 \%$ and $50.4 \%$, respectively). The mean CD4 and CD8 T cell subset count in general inhabitants was $849 \pm 20$ and $646 \pm 19$, respectively. The mean of CD4 and CD8 T cell subset count in household contacts was $785 \pm 13$ and $572 \pm 15$, respectively. No statistically significant differences were found in peripheral blood CD4 and CD8 count between general inhabitants and household contacts. In general inhabitants the mean CD4 and CD8 count showed significant difference between individuals with positive IgM antibodies to PGL-I compared to individuals with negative IgM antibodies to PGL-I. Although individuals with positive IgM antibodies to PGL-I might not suffering clinical manifestation of leprosy, the finding of positive IgM and low number of CD4 count still support the theory of a high risk to contract lepromatous leprosy.
\end{abstract}

Keywords: general inhabitant, household contact, lepromatous leprosy, tuberculoid leprosy

Leprosy is a chronic infectious disease caused by Mycobacterium leprae. The disease has a broad spectrum of clinical manifestation from the tuberculoid form, with low bacillary load, to the lepromatous form, with high bacillary load, and may lead to irreversible physical deformities and extensive damage of peripheral nerves. The spectrum of this disease activity is best classified to five groups as follows: full tuberculoid (TT), Borderline tuberculoid (BT), mid borderline (BB), borderline lepromatous (BL), and full lepromatous (LL). ${ }^{1}$

Department of Medical Microbiology, Faculty of Medicine, Hasanuddin University. Ujung Pandang, Indonesia
In TT and BT leprosy the T lymphocytes of CD4+ subset are the most abundant lymphocytes which are typically present in the central region of the granulomas, while the $\mathrm{CD} 8+\mathrm{T}$ lymphocytes are present as a mantle around the epitheloid structures. A characteristic serologic feature of TT and BT leprosy is low antibody response to $M$. leprae.

In LL leprosy there is poor cell-mediated immune response and high antibody response to $M$. leprae. It has been reported previously that the detection of IgM antibodies to phenolic glycolipid-I (PGL-I) using Mycobacterium leprae particle agglutination (MLPA) test in the community may be useful for the follow up of subclinical infection of leprosy among individuals living in an endemic area. ${ }^{2,3} \mathrm{We}$ have also demons- 
trated the homogeneity of seropositivity among populations at village level in South Sulawesi, Indonesia, and suggested that seropositivity in a population meant an endemic exposure to $M$. leprae. Indeed, we also found evidence of cluster of leprosy in certain villages. ${ }^{4,5}$

The subset of CD4+ T cell became central to considerations of protection and pathology in human disease. Therefore we analyze the correlation between positivity of IgM antibodies to Phenolic Glycolipid-I (PGL-I) of M. leprae and T cell subset (CD4 and CD8) count to determine the risk factors among individuals through a total population survey in an area where leprosy is endemic, in Indonesia.

\section{METHODS}

\section{Field study}

An isolated village in a rural area of South Sulawesi, Indonesia, with 3074 inhabitants was selected for the survey. The leprosy prevalence was expected to be $0.64 / 1,000$ on the basis of available information from the local health service. Before the study was undertaken, the individuals of the village were informed on the purpose of the study, and written consent was obtained from all participants. Only individuals living in the village for at least three months and giving their consent were included in the study.

Clinical examination was carried out by experienced leprosy worker and diagnosis of leprosy was based on the classification of Ridley and Jopling. ${ }^{\text {' Slit skin }}$ smears were taken from earlobes and a sample from one lesion at least, from all leprosy patients for the determination of the bacterial index (BI).

\section{Blood collection}

Blood samples were collected by venipuncture (1.0 $\mathrm{ml}$ ). Samples were centrifuged $3000 \mathrm{rpm}$ for 5 minutes to separate the serum and transfered to $500 \mu \mathrm{l}$ vials (Sarstedt, Assist Trading Co., Ltd.) on the same day. All sera were stored at $-4^{\circ} \mathrm{C}$ for further analysis.

The samples collected from individuals were coded, and serological tests were performed without prior knowledge of the classification of the samples.

\section{MLPA test}

The Serodia-leprae microtitre particle agglutination test kit for the detection of anti-PGL-I antibodies was purchased from Fujirebio Inc., Japan. ${ }^{6}$
Serum samples were diluted to 1:16 and 1:32 in 96 well U-bottom microplates. Twenty five $\mu$ l of unsensitized gelatin particle and $25 \mu \mathrm{l}$ of the particles sensitized with synthetic trisacharide of PGL-I (NT-P-BSA) were mixed with $25 \mu \mathrm{l}$ of $1: 16$ and $25 \mu \mathrm{l} 1: 32$ diluted samples, respectively. After being incubated for 2 hours at room temperature, the plate was read for agglutination using a mirror reader. Serum samples showing agglutination at a titre of $\geq 1: 32$ were considered positive. Positive sera were serially diluted to a concentration of 1:1024 for quantitative testing.

\section{ELISA}

IgM and IgG antibodies to PGL-I and LAM-B in serum was measured by indirect ELISA. An ELISA plate (Nunc-Immunoplate Maxsorp F96) was coated with 50 $\mu \mathrm{l}$ of PGL-I or LAM-B solution $(0.1 \mu \mathrm{g} / \mathrm{ml}$ in carbonate buffer, $\mathrm{pH}$ 9.6), and then the free surface of the well was blocked by incubation with $1 \% \mathrm{BSA}$ at $37^{\circ} \mathrm{C}$ for 60 minutes. The test serum, diluted to $1: 300$ with dilution buffer (PBS with $20 \%$ fetal calf serum and $0.5 \%$ Tween 20 ), was added to the well and incubated at $37^{\circ} \mathrm{C}$ for 60 minutes. After rinsing the plate with washing buffer, peroxidase-conjugated anti-human IgM or IgG antiserum (Dako immunoglobulins $\mathrm{A} / \mathrm{S}$ ) was added to the well and incubated at $37^{\circ} \mathrm{C}$ for 60 minutes. After the excess conjugate was removed using washing buffer, substrate solution $(0.4 \mathrm{mg}$ of ophenylenediamine per $\mathrm{ml}$ and $0.4 \mu \mathrm{l}$ of hydrogen peroxide per $\mathrm{ml}$ in $0.1 \mathrm{M}$ citrate-phosphate buffer, $\mathrm{pH}$ 5.0) was added and the plate was developed in the dark for 15 to 30 minutes. The reaction was stopped with $1.25 \mathrm{M}$ sulfuric acid. The absorbance was then measured with a microplate photometer at $490 \mathrm{~nm}$.

\section{Counting of CD4/CD8 $\mathrm{T}$ cell subset}

The counting of CD4/CD8 $\mathrm{T}$ cell subset was established in Dynabeads T4-T8 Quant (Dynal kit, Oslo, Norway). Briefly, $0.5 \mathrm{ml}$ of blood was collected by venipuncture and counts of CD4/CD8 were performed at the same day. The Dynabeads T4-T8 kit uses magnetic particles coated with antibodies to the CD4 and CD8 antigen to capture and isolate T4 and T8 lymphocytes from whole blood. The isolated cells are lysed and counted directly in haemocytometer after staining with Sternheimer-Malbin solution.

First $250 \mu \mathrm{l}$ blood in EDTA was rotated for 2 minutes at room temperature and $225 \mu \mathrm{l}$ washing/dilution buffer was added. For monocytes depletion $25 \mu \mathrm{l}$ Dynabeads anti CD14 was added and incubated in a tilting and rotating action for 10 minutes. The tube was 
placed in the Dynal MPC-Q for 2 minutes and carefully $200 \mu \mathrm{l}$ of monocyte-depleted blood was transfered into each of two supplied microtubes. The tube containing the rosetted monocytes was disposed.

For the isolation of CD4/CD8 $\mathrm{T}$ cell subset, into one of the two microtubes containing $200 \mu \mathrm{l}$ monocyte depleted blood, $200 \mu \mathrm{l}$ washing/dilution buffer and 25 $\mu 1$ Dynabead CD4 was added, and to the other $25 \mu 1$ Dynabead CD8. The tubes were capped and mixed carefully by turning and incubated for 10 minutes. The tubes were placed in the Dynal MPC-Q for 2 minutes and the supernatant was discarded. The isolated cells were washed by adding $500 \mu \mathrm{l}$ washing/dilution buffer and placed in the Dynal MPC-Q for a few minutes and the washing step was repeated once. The cells were resuspended in $80 \mu \mathrm{l}$ lysis buffer and vortexed, and leaved for 5 minutes. Again the cells were vortexed and the tubes were leaved in the MPC-Q for 1 minute to separate the Dynabeads from nuclei. Twenty $\mu \mathrm{l}$ Sternheimer-Malbin staining solution was added and the nuclei were counted in a haemocytometer.

\section{Data analysis}

All data were recorded on special forms and analysed using a statistical software package (Epi-Info, version $6.02)$ in appropriate hardware. Statistical analysis was applied as indicated in the results. All $P$ presented are two-tailed $P$ value.

\section{RESULTS}

\section{Sample size and incidence rate}

At this survey, from 3047 people that were registered a total of 2349 inhabitants ( $76 \%$ of registered population) met the inclusion criteria and was clinically examined for signs of leprosy. Twenty nine new leprosy patients were detected during the survey and 2 patients had been identified years before by the local health service, giving a total of 31 leprosy patients ( 20 males and 11 females), ranging in age from 12 to 67 years. Based on the slit skin smear results and clinical diagnosis, 27 patients were classified as tuberculoid and four as lepromatous (bacterial indices of slit skin smears ranging from 1.0 to 4.0 ). There was a significant difference in leprosy patients between males and females $(P<0.05)$. The indicende rate among the population was thus $10.0 / 1000$ population.

The male : female ratio in the examined population was 0.82 compared with 0.90 in the registered population (Figure 1).
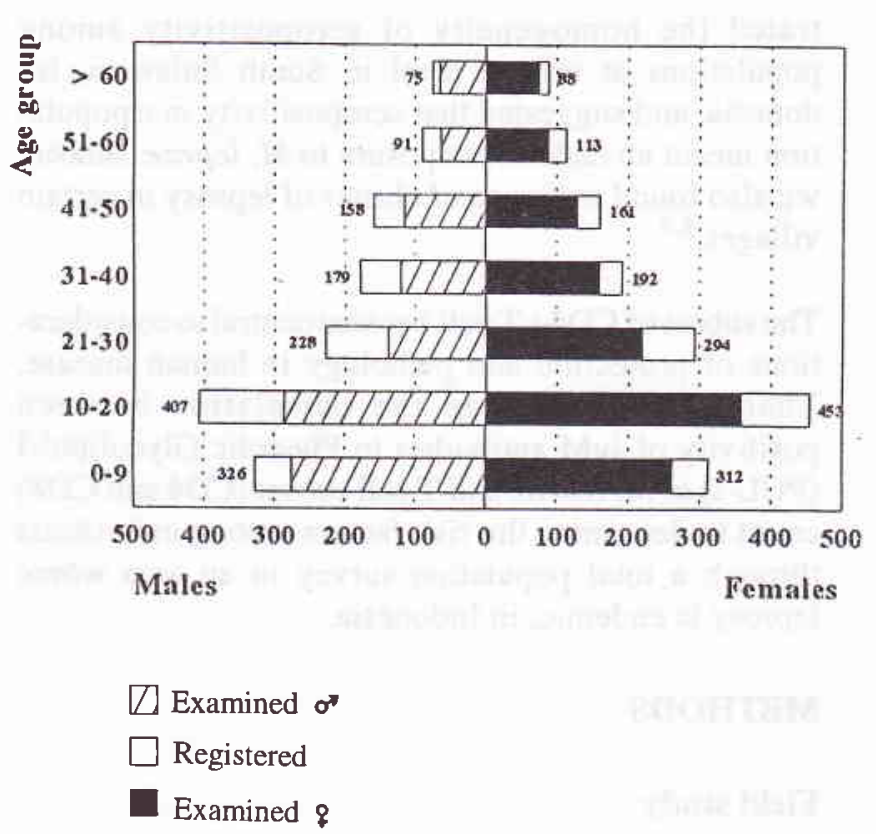

Figure 1. Distribution of registered and examined population according to age and sex in Tukamasea village

Difference in sex group among registered population and examined population is not significant (Fischer exact test, $P>0.05$ )

\section{Seropositivity rate to $M$. leprae related antigens in general inhabitants and household contacs}

As it was not feasible to test all individual samples in this survey by Mycobacterium leprae particle agglutination MLPA test and ELISA, we examine 1483 general inhabitants (NC group) and 73 household contacts (HC group). As shown in Table 1, using ELISA to detect anti PGL-I IgG antibody, the seropositivity rate in male and female in NC group was $7.8 \%$ and $6.4 \%$, respectively. However, the rate of IgM positive in male and female in NC group was $31.7 \%$ and $46.5 \%$, respectively. The rate of IgM positive in female was significantly higher than in male in the NC group (Fischer exact test, $P<0.01$ ).

Using ELISA to detect anti LAM-B IgG antibody, no difference was found in seropositivity rate of LAM-B IgG between male and female in both the $\mathrm{NC}$ and the HC group (Fischer exact test, $P>0.01$ ), while the seropositivity rate of PGL-I IgM in female was significantly higher than in male in the HC group (Fischer exact test, $P<0.01$ ). 
Table 1. MLPA and ELISA results using $M$. leprae antigen in general inhabitants and household contacts

\begin{tabular}{|c|c|c|c|c|c|c|c|}
\hline \multirow[t]{2}{*}{ Group } & \multirow[t]{2}{*}{ Antigen } & \multirow[t]{2}{*}{$\operatorname{IgM} / \operatorname{IgG}$} & \multirow[t]{2}{*}{ Methods } & \multicolumn{2}{|c|}{ Male } & \multicolumn{2}{|c|}{ Female } \\
\hline & & & & Positive $\ddagger$ & Negative $\ddagger$ & Positive $\neq$ & Negative $\ddagger$ \\
\hline \multirow[t]{4}{*}{$\mathrm{NC}^{*}$} & PGL-I & $\operatorname{IgG}$ & ELISA & $51(7.8)$ & $602(92.2)$ & $53(6.4)$ & $777(93.6)$ \\
\hline & PGL-I & IgM & ELISA & $207(31.7)$ & $445(68.3)$ & $386(46.5)$ & $444(53.5)$ \\
\hline & PGL-I & $\operatorname{IgM}$ & MLPA & $210(32.2)$ & $443(67.8)$ & $400(48.2)$ & $430(51.8)$ \\
\hline & LAM-B & IgG & ELISA & $140(21.4)$ & $513(78.6)$ & $137(16.5)$ & $693(83.5)$ \\
\hline \multirow[t]{4}{*}{$\mathrm{HC}+$} & PGL-I & IgG & ELISA & $5(16.7)$ & $25(83.3)$ & $3(7.0)$ & $40(93.0)$ \\
\hline & PGL-I & $\operatorname{IgM}$ & ELISA & $10(33.3)$ & $20(66.7)$ & $29(67.4)$ & $14(32.6)$ \\
\hline & PGL-I & IgM & MLPA & $11(36.7)$ & $19(63.3)$ & $30(69.8)$ & $13(30.2)$ \\
\hline & LAM-B & IgG & ELISA & $5(16.7)$ & $25(83.3)$ & $6(14.0)$ & $37(86.0)$ \\
\hline
\end{tabular}

${ }^{*} \mathrm{NC}=$ General Inhabitants, $\mathrm{HC} \dagger=$ Household contacts, $\ddagger$ Absolute number $(\%)$, Cut off for positive to PGL-I IgG (ELISA) $=80$, PGL-I IgM $($ ELISA $)=380$, PGL-I IgM $($ MLPA $)=32$, LAMB IgG $($ ELISA $)=250$

Using MLPA test to detect anti PGL-I IgM antibody, the seropositivity rate in female was significantly higher than in male in both the $\mathrm{HC}$ and the NC group (Fischer exact test, $P<0.01$ ).

In addition, no significant difference was found in seropositivity rate between $\mathrm{HC}$ group and $\mathrm{NC}$ group by ELISA or MLPA (Fischer exact test, $P>0.01$ ).

\section{Number of CD4 and CD8 T cell subset in general inhabitants and household contacts}

Among the 1483 general inhabitant (NC group) and 73 household contact (HC group) samples tested by Dynabead method, the mean of CD4 and CD8 count in the NC group was $849 \pm 20$ and $646 \pm 19$, respectively; while CD4/CD8 ratio in the NC group was $1.45 \pm$ 0.058 . The mean of CD 4 and CD8 count in the $\mathrm{HC}$ group was $785 \pm 13$ and $572 \pm 15$, respectively; while $\mathrm{CD} 4 / \mathrm{CD} 8$ ratio in the $\mathrm{HC}$ group was $1.44 \pm 0.074$. No statistically significant difference in the mean of CD4 and CD8 count was found between the two groups (Student's t test, $P>0.01$ ) (Table 2).

Table 2. CD4 and CD8 count in general inhabitans and household contacts

\begin{tabular}{lccc}
\hline Group & $\begin{array}{c}\text { CD4 } \\
\text { count* }\end{array}$ & $\begin{array}{c}\text { CD8 } \\
\text { count* }\end{array}$ & $\begin{array}{c}\text { CD4/CD8 } \\
\text { ratio* }\end{array}$ \\
\hline General Inhabitans & $849 \pm 20$ & $646 \pm 19$ & $1.45 \pm 0.058$ \\
Household contacts & $785 \pm 13$ & $572 \pm 15$ & $1.44 \pm 0.074$ \\
\hline
\end{tabular}

* Mean \pm SD

No statistically significant difference in CD4 and CD8 count between the two groups

\section{Correlation between seropositivity and CD4 and CD8 count}

The correlation between seropositivity and $\mathrm{CD} 4$ and CD8 count is shown on Table 3. There was significant difference in the mean of $\mathrm{CD} 4$ and $\mathrm{CD} 8$ count between anti PGL-I IgM seropositive and seronegative (Student's t test, $P<0.01$ ).

However, there was no significant difference in the mean of CD4 and CD8 count between anti PGL-I IgG seropositive and seronegative (Student's test, $P>$ $0.01)$.

There was no significant difference in the mean of CD4 and CD8 count between anti LAM-B IgG seropositive and seronegative (Student's $t$ test, $P>0.01$ ).

Table 3. Corelation between seropositivity and CD4 and CD8 count

\begin{tabular}{|c|c|c|c|}
\hline $\begin{array}{l}\text { Antibodies } \\
\text { Positive/Negative }\end{array}$ & $\begin{array}{l}\text { CD4 } \\
\text { count* }\end{array}$ & $\begin{array}{l}\text { CD8 } \\
\text { count* }\end{array}$ & $\begin{array}{c}\text { CD4/CD8 } \\
\text { ratio* }\end{array}$ \\
\hline Anti PGL-I IgM (+) & $949 \pm 10^{*}$ & $735 \pm 16$ & $1.28 \pm 0.06$ \\
\hline $\begin{array}{c}\text { Anti PGL-I IgM (-) } \\
P \text { value }^{\dagger}\end{array}$ & $\begin{array}{l}635 \pm 12 \\
\text { sign }\end{array}$ & $\begin{array}{c}528 \pm 9 \\
\text { sign }\end{array}$ & $\underset{\mathrm{ns}}{1.21 \pm 0.09}$ \\
\hline Anti PGL-I IgG (+) & $893 \pm 26$ & $683 \pm 14$ & $1.35 \pm 0.10$ \\
\hline $\begin{array}{c}\text { Anti PGL-I IgG (-) } \\
P \text { value }\end{array}$ & $\underset{\mathrm{ns}}{855 \pm 14}$ & $\underset{\mathrm{ns}}{648 \pm 15}$ & $\begin{array}{c}1.46 \pm 0.08 \\
n s\end{array}$ \\
\hline Anti LAMB IgG (+) & $821 \pm 17$ & $644 \pm 23$ & $1.35 \pm 0.05$ \\
\hline Anti LAMB IgG (-) & $867 \pm 28$ & $658 \pm 27$ & $1.47 \pm 0.08$ \\
\hline$P$ value & $\mathrm{ns}$ & $\overline{n s}$ & ns \\
\hline
\end{tabular}

* Mean $\pm S D$ (of the number or ratio of $T$ cell subset, using Dynabeads method)

$\dagger$ The difference between individuals with positive and negative antibodies, in the number of CD4/CD8 count and CD4/CD8 ratio was measured by student's $\mathbf{t}$ test, sign $=$ significant, ns $=$ non significant 


\section{DISCUSSION}

In this study, we demonstrated the applicability of MLPA test and CD4/CD8 $T$ cell subset as high risk indicator in subclinical infection among individuals by active survey in an area where leprosy is endemic.

The population in this survey did not differ from the total population both in sex and age group and the sample could be considered as representable. Therefore it is justified to extrapolate the serological results to the whole population of this village, giving an incidence rate of 10.0/1000 population.

In this survey, we found that the seropositivity rate to PGL-I IgM antibody by MLPA test among general inhabitants was $40.2 \%$. In a previous survey, in the area of South Sulawesi, Indonesia, we found that the seropositivity rate by the same test among general population was $31.9 \% .^{2}$ The results of other epidemiological studies performed in North Sulawesi also showed that patient to patient contact is the mayor determinant in leprosy incident, with implication for future control. The above study revealed the contact with a leprosy patient is the major determinant in leprosy incident, whereby the contact was not limited only to household relationships, but also includes neighbour and social relationships. ${ }^{7}$ Thus, many normal persons in the community in an area of high leprosy prevalence have increased anti PGL-I IgM, presumably as a consequence of previous subclinical infection. Our results however revealed that many subjects with positive anti PGL-I IgM did not show any clinical sign. Therefore, one can hypothesize that the majority of individual exposed to $M$. leprae can defend themselves effectively against the development of the disease. However, it remains unclear why in some individual the disease could develop progressively to lepromatous. It might be suggested that the clinical manifestation of this disease might be determined by a complex of immune mechanisms, involving the mechanism by which this bacteria evaded or triggered the cell mediated or humoral immune response. ${ }^{8}$ In this study, we found that the mean of CD4 and CD8 count in anti PGL-I IgM seropositive was significantly higher than in the seronegative individuals. While the immunological significance of this correlation remains obscure, this study revealed that in most of tuberculoid type of leprosy that was found by active survey they have high cellular immunity to $M$. leprae. Thus, it seems that cell mediated mechanisms of immunity rather than humoral are associated with the protection and clinical status of disease.
In this study, the seropositivity rate in general inhabitants and household contacts in females were significantly higher than in males. This is in accordance with previous reported studies, ${ }^{9,10}$ and our former observations. ${ }^{3}$ The higher MLPA, ELISA, anti GPL-I IgM and ELISA anti LAM-B IgM positivity rates among females did not reflect a higher case rate in our study. Higher innate IgM levels among females compared to males is the most simple explanation for this phenomenon. ${ }^{11}$ However, other factors related to the endemicity and the specific life style (if any) of the population should be taken into account. In contrast, there was no significant difference in ELISA anti PGLI IgG or ELISA anti LAM- B IgG between males and females.

Our previously described MLPA test was suitable for detecting IgM antibody in a large population in leprosy endemic areas, ${ }^{3}$ and no clustering of MLPA seropositivity was observed among the population. ${ }^{4}$

Several reports indicated that the predominant anti PGL-I response in most human leprosy patients was of the IgM type, ${ }^{12}$ and that anti PGL-I IgM levels were correlated with disease classification, increasing from the tuberculoid toward the lepromatous pole of the disease spectrum. ${ }^{13}$

To better understand the correlation of IgM antibodies and CD4 and CD8 count with the maintenance of subinfection, we applied MLPA test and Dynabead method through a survey and we will reexamine the same individuals living in an area in which leprosy is endemic.

\section{CONCLUSION}

In general inhabitants the mean of $\mathrm{CD} 4$ and $\mathrm{CD} 8$ count showed significant difference between individuals with positive IgM antibodies to PGL-I compared to individuals with negative IgM antibodies to PGL-I. Although individuals with positive IgM antibodies to PGL-I might not suffering clinical manifestation of leprosy, the finding of positive IgM and low number of CD4 count still support the theory of a high risk to contract lepromatous leprosy.

\section{Acknowlegments}

We thank Dr. Paul R Klatser, Dr. Stella M van Beers and Dr. Shinzo Izumi for critical reading of the manuscript. We would like to express our gratitute to the Head of the South Sulawesi Office of the Ministry of Health, Republic of Indonesia and the Head of 
Leprosy Unit of the Ministry of Health, Republic of Indonesia for their cooperation. The financial support of The Netherlands Leprosy Relief Association (NSL) and Pfeizer Health Research Foundation of Japan is greatly appreciated.

\section{REFERENCES}

1. Ridley DS, Jopling WH. Classification of leprosy according to immunity: a five-group system. Int J lepr 1966;34:255-73.

2. Hatta M, Izumi S, Klatser PR. Evaluation of Mycobacterium leprae particle agglutination (MLPA) test as a tool in the epidemiology of leprosy in high prevalence village in South Sulawesi, Indonesia. Southeast Asia J Trop Med Pub Health 1995;4:631-5.

3. Izumi S, Hatta M, Kawatsu K, Matsuoka M. Seroepidemiological study of $M$. leprae infection in the inhabitants of endemic villages in South Sulawesi, Indonesia. Int J Lepr 1995;63:650.

4. Hatta M, van Beers SM, Madjid B, Achmad D, de Wit MYL, Klatser PR. Distribution and persistence of Mycobacterium leprae nasal carriage among a population in which leprosy endemic in Indonesia. Trans $\mathrm{R}$ Soc Trop Med Hyg 1995;89:381-5.

5. Hatta M, Izumi S. Present situation of leprosy in Indonesia and future prospect: Molecular epidemiological and Seroepidemiological study of leprosy in South Sulawesi, Indonesia. Int Sci Meeting of International Epidemiological Association; 1996 August 27-30; Nagoya, Japan.

6. Izumi S, Fujiwara T, Ikeda M, Nishimura Y, Sugiyama K, Kawatsu K. Novel gelatin particle agglutination tests for serodiagnosis of leprosy in the field. J Clin Microbiol 1990;28:525-9.

7. van Beers SM, Hatta M, Klatser PR. Patients contact is the major determinant in incident leprosy: Implications for future control. Int J leprosy. 1998 submitted.

8. Muthukkarupan VR, Chakkalath HR, Malarkannan S. The classical and alternative pathways of $\mathrm{T}$ cell activation are impaired in leprosy. Immunol Lett 1982;19:55-8.

9. Fine PE, Ponnighaus JM, Burgess P, Clarkson JA, Draper CCM. Seroepidemiological studies of leprosy in norhem Malawi base on an enzym-linked immuno-sorbent assay using synthetic glycoconjugate antigen. Int J Lepr 1988;56:243-54.

10. Ulrich M, Smith PG, Sampson C, Zuniga M, Centeno M, Garcia V, et al. IgM antibodies to native glycolipid-I in contacts of leprosy patients in Venezuela: epidemiological observation and a prospective study of the risk of leprosy. Int J Lepr 1991;59:405- 15.

11. Maddison SE, Stewart CC, Farshy CE, Reimer CB. The relationship of race, sex and age to concentrations of serum immunoglobulins expressed in international units in healthy adults in the USA. Bull WHO 1975;52:179-85.

12. Levis WR, Meeker HC, Schuller-Levis G, Sersen E, Schwerer B. IgM and IgG antibodies to phenolic glycolipid-I from Mycobacterium leprae in leprosy: insight into patient monitoring, erythema nodosum leprosum and bacillary persistence. J Invest Dermatol 1986;86:529-34.

13. Brett SJ, Payne SN, Gigg J, Burgess PJ, Gigg R. Use of synthetic glycoconjugates containing Mycobacterium leprae specific and immunodominant epitope of phenolic glycolipid-I in serology of leprosy. Clin Exp Immunol 1986;64:476-83. 